\title{
Chronology of Italian Political Events, 2000
}

\section{January}

1 The Treasury minister, Giuliano Amato, announces, "Never, in the past twenty years, has Italy's deficit been this low." Italy falls under the 2 percent ratio between deficit and GDP as established by the Maastricht Treaty.

2 The laws known as "single judge" become effective. Strongly advocated by the minister Oliviero Diliberto, this legislation was opposed by the magistrates.

Politicians begin to criticize the organization of the Jubilee due to the difficulties met by tourists and pilgrims returning home after celebrating the year's end and the beginning of the Holy Year.

5 European stock exchanges fall for the third consecutive day because of rumors interest rates will rise in the US.

The government sets the date for regional elections: 16 May. The president of the Senate, Nicola Mancino, advocates a law that will give parties equal time on TV; it is the par condicio. After the laws on the "single judge," the decree on "fair trial" is also approved without opposition from the existing judges.

7 Prime Minister Massimo D’Alema criticizes "social” referenda proposed by the Radicals on the ground that it "threatens to tear apart the social pact."

The CISL Secretary, Sergio D'Antoni, announces that he is disappointed by the Prime Minister's action, stating that "the D’Alema II is politically weak."

8 All the parties concerned by the issues subject to the referenda give interviews in which they come out for or against, especially insofar as the "social" questions are concerned: the Con- 
findustria and the Radical promoters of the referenda are for, the trade unions and most of the Center-Left against. Arturo Parisi, the leader of the Democrats, threatens to punish Antonio Di Pietro for his constant criticism of the party's leadership.

11 Two days before the DS's Congress begins at the Turin Lingotto, Parisi suggests to Veltroni that their respective parties should dissolve "in a path toward unity."

The Polo's leader, Silvio Berlusconi, strongly objects to the difficult agreement the center left's heterogeneous components are reaching on the launch of the par condicio law. Berlusconi refers to the law as "liberticidal."

The Industry minister, Enrico Letta, meets with representatives of the oil industry in an attempt to contain rising gasoline prices due to increases in the price of oil.

13 Veltroni, speaking at the DS' Congress, rejects Parisi's proposal, by arguing that the path the Center-Left should follow is that of a "federation of parties," rather than a single party.

14 First critical interventions at the DS' Congress. Amidst much applause, Sergio Cofferati, the CGIL secretary, asks the CenterLeft government to side openly against the "social" referenda; the mayor of Naples, Antonio Bassolino, leaves the Congress; the former secretary, Achille Occhetto, asks D'Alema to step aside. The Polo criticizes the "excessive overtones" used by the Congress against Berlusconi.

15 D'Alema's speech arouses the Congress, fostering confidence in the government's action and the expectation they will prevail at the regional elections. Veltroni is confirmed as party secretary with nearly 80 percent of the delegates' votes.

19 Bettino Craxi, the former PSI leader, dies in Hammamet, Tunisia. His daughter, Stefania, harshly criticizes the government; Berlusconi announces his deep grief; D’Alema declares a State funeral.

20 Four of the people in charge of the humanitarian "Rainbow" mission the government organized to bring aid to Albania are arrested; the Polo calls for the resignation of the under-secretary to the Interior in charge of Civil Defense, Franco Barberi.

21 Foreign Affairs minister, Lamberto Dini, and Marco Minniti, the under-secretary to the Prime Minister, are harshly questioned while attending Craxi's funeral.

22 The Venice Appeals Court confirms the conviction of Adriano Sofri, Giorgio Pietrostefani and Ovidio Bompressi, in connection with the murder of Police Superintendent Luigi Calabresi. Sofri's lawyers announce they will appeal to the Court of Cassation, while Pietrostefani and Bompressi disappear. Amidst 
polemics, Parliament considers launching a congressional investigation on Tangentopoli.

25 A lively parliamentary session occurs in the Chamber on the par condicio. Outside, Forza Italia manifests its opposition by staging a protest demonstration.

26 In anticipation of the regional elections and in spite of the opposition the National Alliance secretary, Gianfranco Fini, Berlusconi attempts to reach an agreement with Francesco Cossiga, leader of the "clover" movement that groups some centrist parliamentarians, and with Umberto Bossi, leader of the Lega.

The rate of inflation 2 percent is higher than expected.

\section{February}

1 The polemic against the Austrian leader Haider causes D'Alema to compare Haider's party to the Lega. Bossi says he's close to "his Austrian friend." Berlusconi claims to fear xenophobia, but accuses the Left of falsification.

Enzo Bianco, in a press conference, says he's satisfied with the instructions to halt soccer games where racist songs, banners, or behavior to occur.

Paolo Pillitteri, Milan's former mayor and Craxi's brother in law, is acquitted of corruption charges related to the Piccolo Teatro.

3 The Constitutional Court rejects fourteen of the twenty-one referenda questions proposed primarily by the Radicals.

The Chamber passes the law on the par condicio amidst the Polo's vocal protest.

The Dutch company KLM threatens to cancel its agreement with Alitalia because of the lack of open decision-making surrounding "the development of Malpensa."

4 D'Alema asks the opposition to dialog with the government concerning the electoral law in order to avoid one of the seven referenda, which proposes the abolition of the proportional quota. Bassolino resigns as mayor of Naples and announces his candidacy for the presidency of the Campania region. The Popolari secretary, Pierluigi Castagnetti, obviously disappointed, bitterly complains that the candidate was chosen without prior consultation.

6 Major success of the first Sunday without cars, launched with the strong support of Environment minister Edo Ronchi.

The case of a prisoner who has been let out of jail with a permit and subsequently committed a homicide in the center of 
Milan, raises much indignation and protest among the public; the government promises to take action, and exercise greater strictness in granting permits and releases from prisons.

9 The President of the Republic Carlo Azeglio Ciampi, pleas for governmental stability, suggesting this stability should be achieved either through Parliament-initiated reforms or through the referenda.

The Center-Left has troubles designating candidates for the regional presidencies.

The Polo obstructs the par condicio in the Senate, while Berlusconi claims the outcome of elections conducted according to rules decided by the majority would be "illegitimate."

Forza Italia's leader also celebrates his third court of appeal acquittal (following the trials concerning the Macherio mansion and the All Iberian company) for allegedly faking the books in the acquisition of Medusa SpA.

10 Two giants, Seat and Telecom's Tin.it merge. The stock exchange reacts very positively to the news and keeps climbing, as it has done nearly uninterruptedly since the beginning of the year, especially as far as the new economy stocks are concerned.

Bianco suggests prisoners on probation wear electronic bracelets and is criticized by components of the majority.

11 The minister of Education, Luigi Berlinguer, is forced to suspend the much contested "quiz-based" competition that would have established merit ranking for teachers' new wage increases.

13 Especially dramatic weekend on the roads: thirty are killed in car accidents.

14 For the first time "green gasoline" costs more than 2.000 IL (slightly less than a dollar per liter).

16 After a month of repeated polemics between the Labor minister, Cesare Salvi, the Confindustria and the Trade unions on how to assign the "tfr" (severance pay), a bad mood spreads within the majority between D'Alema and most of his centrist allies.

Berlusconi announces the birth of the Freedoms House, a bloc that also includes the Lega, Cossiga's Clover, and Rocco Buttiglione's CDU; attempts to aggregate the Radicals also begin.

20 Amato declares reforms are possible even without the agreement of the Unions; the concerned organizations, as well as many exponents of the majority, reply bitterly.

22 During the San Remo festival of Italian Song, the singer Jovanotti asks D'Alema on live TV to erase the debt of the poorest developing countries; the Polo is criticized for describing the episode as "a publicity spot for the Prime Minister". 
Police denounce alleged pressures by the Carabinieri on Parliament concerning the imminent reform of the force.

27 After weeks of intense bargaining, the agreement between the Radicals and the Casa della Liberta' breaks down.

28 The Milan stock exchange reaches a record high, led by new economy titles.

The PPI selects Gerardo Bianco, the former Popolari Secretary, as its candidate for the presidency of Campania - a clear protest against Bassolino’s self candidacy.

\section{March}

2 The law on school parity is definitively approved. The Polo and the Bishops claim that it is "unfinished and ambiguous legislation." Rifondazione and the school Cobas protests as well.

3 The Government issues a decree establishing harsher punishments and allowing for more extensive investigations for serious tax evasion crimes.

4 Minister Bianco gives back to the special corps of the police (SCO, ROS and GICO) most of the prerogatives former minister Giorgio Napolitano had taken away from them.

7 Bompressi, after having been in hiding for more than twenty days, gives himself up and goes back to prison; Pietrostefani is rumored to have already fled to France, a country where his crimes have already become statute-barred and which will not extradite him.

Responding to the government's statement about the negative inflationary impact of increased insurance rates, Alfonso Desiata, sends the accusation back to the sender.

8 Antonio D'Amato, a businessman "of the South and of small enterprises," is unexpectedly elected president of Confindustria instead of Carlo Callieri who had the support of large industrial groups; his first statement sings the praise of the group's newfound "combativeness."

12 The agreement between Fiat and US General Motors is signed. Gianni Agnelli says he prefers the Americans' proposal to that of the Germans from Daimler-Chrysler, because the former allowed the family to retain its control over the company; politicians, industrialists and unionists from all sides react positively.

13 A week of protest by doctors who are being forced to choose between private and public practice by the reform enacted by the Health minister, Rosy Bindi, comes to an end. After the deadline is past, it is discovered that nearly 80 percent of the 
doctors chose to continue to practice in the public service. Bindi says she's ready to "curb the big shots' rebellion."

14 Berlusconi now openly states his preference for the proportional system. The Polo is considering allying with Pino Rauti's neo-fascist party (MSI-FT) in some regions.

16 The European Parliament decides that the Savoia's return to Italy is an issue for the Italian Parliament to decide: Prince Vittorio Emanuele indignantly refers to Italy as " a little republic." While the Senate votes in favor of a parliamentary inquiry on Tangentopoli, in Milan, the Forza Italia chairman of the city Council, Massimo de Carolis, is under investigation for corruption.

17 The government launches its highly publicized "anti-inflation" plan: auto insurance rates, water and gas rates are blocked; governmental taxes on oil are reduced further; insurance companies protest.

In view of the upcoming European Council of Lisbon, a joint letter from D'Alema and the British Prime Minister Tony Blair to the European Union states it is necessary to launch a global reform of the labor market rather than relying on dubious measures like shortening the working week.

Agreement occurs between the Polo and Rauti's Movimento Sociale-Fiamma tricolore in some Southern regions: Abruzzo, Basilicata, Campania, Calabria.

Mancino dismisses Vittorio Emanuele di Savoia's statements as the byproduct of ignorance.

20 The unions ask for explanations about the joint D'Alema-Blair letter and denounce its recipes as too laissez-faire; the government belatedly disclaims responsibility for the document.

21 March inflation reaches $2.5 \%$, but the GDP at 2.1 percent is growing strongly by comparison with the standard established in previous years.

Majority and opposition criticize the Prime Minister for a phone call with colonel Antonio Pappalardo, president of the carabinieri's Cocer, in the course of which Pappalardo allegedly asked for the "Benemerita" to receive special treatment in the course of the upcoming reorganization of the security corps.

24 Unemployment is down by 1.1 percent over the year, largely due to term and part-time contracts.

26 A paid ad in the national newspapers by one of the seven police unions denounces the serious situation that would be created if a proposed law were to be approved institutionalizing the carabinieri as the fourth force of the Italian Army. According to the ad, this would create a situation of democratic instability; the references to the "Pappalardo affair" appear obvious. 
30 The very same day in which the carabinieri become the country's fourth armed force, a file put together by Cocer president Pappalardo is found. The file discusses the need to create a new democratic order and to reestablish the current parties that are said to be disconnected from the citizens' needs. Indignant reactions, especially from within the force occur.

31 Pappalardo resigns as Cocer's president after a few days of very intense polemics.

Berlusconi sets sail from Genova on the "Azzurra" ship for his electoral tour.

\section{April}

2 In the course of a car chase with smugglers a customs officer dies and a second is seriously injured, after the criminals ram their car; a wave of indignation and commotion sweeps the country.

4 Tommaso Buscetta, the first major member of the Cosa Nostra and Mafioso to turn informer, dies.

The majority's centrist allies meet to discuss the possibility of verifying whether the coalition's leadership is adequate, especially in light of the 2001 elections, "in order to give more relevance to the center of the Center-Left." Primaries are mentioned, and D'Alema lets it be known he's ready to run, after the regional elections.

9 In an interview with a national daily, D'Alema clearly invites the Radicals to align against the Polo at the regional elections; there are disagreements, especially from PPI secretary, Castagnetti.

11 Flaminio Piccoli, a historic leader of the Christian Democrats, dies.

European stock exchanges, including Milan, continue to fall, due to fear created after the US Supreme Court finds Microsoft guilty of monopolistic practices, calling for its split into several operational sectors.

13 The Calabrese ' $n$ drangheta uses a car bomb to kill the entrepreneur Domenico Gullaci, who objected to paying protection money.

16 At the regional elections, the Center-Left majority loses in nine of fifteen regions; the Polo is enthusiastic as major leaders call for early elections; the majority downplays the implications of the vote as far as the government's existence is concerned, and expresses its confidence in completing the legislature. 
The Milanese financial world worries about the hospitalization of the Mediobanca's ninety-two-year old honorary president, Enrico Cuccia.

17 Following electoral results, D'Alema resigns as Prime Minister "inspired by political sensitivity and not by constitutional duty;" the Polo continues to call for anticipated elections. Several media already point to Amato as D’Alema's successor.

18 A new law on public sector strikes becomes effective, disciplining more strictly such activities, especially in anticipation of Easter's mass exodus.

19 The European Commission threatens to initiate an infringement procedure concerning the transfer of flights from Linate to Malpensa, but the government goes ahead. Relations between KLM and Alitalia worsen.

20 President Ciampi charges Amato with forming a new government. The majority accuses the opposition of trying to "buy" votes of some deputies who belong to the center parties of the Center-Left with money and promises of safe districts. Clemente Mastella makes deputies and senators who belong to his party UDEUR sign a "loyalty pact."

21 Antonio Di Pietro challenges the leadership of his Democrats party, by claiming that Amato, who had been close to Craxi in the most obscurantist years in which corruption was spreading, represents "the old politics." Di Pietro says he will not give Amato his vote of confidence.

24 Tensions rise between Amato and the Democrats concerning the list of ministers, among whom Democrats have only a few representatives.

25 The ministers' list is made public: there is one fewer ministry, and the names of two "technical" ministers stand out: Umberto Veronesi as Health minister, and Tullio De Mauro as Education minister; Ronchi rejects the ministry of Public Works because he would like to stay at the Environment; the two contested education and health reformers, Berlinguer and Bindi, are out.

26 The Polo denounces as scandalous the "undignified rush for posts" of which the majority is allegedly guilty, and declares the Amato government to be "illegitimate." Di Pietro announces he will split from the Democrats.

After having fallen for about a month, gasoline prices begin to climb again, with an expected impact on inflation.

27 Di Pietro leaves the Democrats. The president of the Lazio region, Francesco Storace, writes the minister Bianco asking him not to authorize the homosexual demonstration, "Gay 
Pride," which is scheduled to take place in the streets of Rome in the same year as the Jubilee.

28 Amato receives a larger than expected vote of confidence in the Chamber: 319 votes in favor, 298 against, 5 abstentions. KLM divorces Alitalia because of "excessive uncertainty about Malpensa."

\section{May}

1 The workers' Jubilee is celebrated with a solemn mass for 100,000 people in Tor Vergata that substitutes the traditional, Union-organized First of May Concert.

2 In Naples, nine people die in seven days from heroin.

3 In Sassari, the director of the S. Sebastiano prison, Maria Cristina Di Mauro, is jailed, together with 82 prison guards, for alleged violence against prisoners; the prison guards' association threatens to make its members resign unless legal action is suspended.

The Amato government obtains the Senate's confidence as well. From within the majority's ranks, Di Pietro fiercely attacks the Prime Minister, whom he accuses of being "Craxi's heir."

4 The Polo's obstructionism in the Chamber blocks all government decrees.

The minister of justice, Piero Fassino, presents Parliament with an investment and hiring plan in order to solve the "prison issue;" an amnesty for minor crimes is also discussed.

According to data from Istat, the Italian industry's turnover and orders are growing faster than at any other time in nearly ten years.

6 Di Pietro is expelled from the Democrats.

9 The decree "clean lists" is approved by the Senate as well, but only with the help of AN, which becomes operational in anticipation of the referenda; PPI, SDI and UDEUR leave the chamber, hoping for the quorum to be missed.

Berlusconi is acquitted on appeal against an accusation of having bribed the Internal Revenue Service; other connected crimes become statute-barred.

11 Berlusconi announces he will not go to the polls for the referenda. D'Antoni takes advantage of the pre-electoral climate surrounding the referenda to declare his opposition to the "anti-proportional" referendum, and also to suggest the creation of a new center movement that would provide an alternative to the two poles. 
12 Due to excellent results in the collection of taxes, the government has at its disposal a "fiscal bonus" of 20,000 billion IL for its budget.

According to government statistics, each year there are a million work-related injuries and 1,200 deaths.

15 The Confindustria asks for a yes vote on the "social" referenda. Berlusconi asks Amato to resign if the referenda do not reach the quorum, since parts of the majority (DS and Democrats, especially) have expressed strong support for the "anti-proportional" question.

The Milan stock exchange begins staying open for business at night, but there are few trades.

16 Coop employee, Alessandro Geri, is arrested under suspicion of having participated in the terrorist band that killed Massimo D’Antona: Geri claims his innocence.

The motivations of Andreotti's acquittal are made public: the judges found no evidence for any of the accusations that the Palermo Public Prosecutor's office made against the Life Senator.

18 The government, seeking to contain gasoline prices, freezes the "carbon tax."

Storace turns to Amato as well, and asks him to prevent the "Gay Pride" demonstration.

19 The stock exchange drops sharply: - 4 percent.

2132.8 percent vote at the referenda: the quorum is not reached for any of the questions. The Polo calls for a technical government: the majority's centrists celebrate. Amato says the electoral law needs to be changed anyway, on the blueprint of the German model.

24 Amato's characterization of "Gay Pride" as "inappropriate" causes some embarrassment; Storace publicly thanks him, whereas gay groups protest loudly.

Demonstrators and police clash at the door of the exhibit-symposium "Tebio" in Genova, in which modified foods and genetic manipulation are discussed.

The Italian Bishops' Conference asks for an amnesty decree in the Jubilee year.

26 Gianni De Gennaro is the new head of the police; he takes Ferdinando Masone's place.

Geri is let out of jail because his alibi "holds." The opposition criticizes Bianco for having interfered with the investigation.

29 After several weeks of controversy, Rutelli withdraws Rome City Hall's support of "Gay Pride."

Inflation is up 2.5 percent. 
31 In his commentary accompanying the publication of the annual report on the Italian economy, the Bank of Italy's governor, Antonio Fazio, criticizes Center-Left governments on many counts; for the majority, the governor ignores "the efforts that have been made;" for the opposition, "the left flunked."

A carabinieri corporal reveals that the Force's archives contain about 70,000 confidential dossiers on individual citizens and organizations.

\section{June}

1 Controversies about "Gay Pride” still abound. Rome City Hall, police, and gay organizations cannot reach an agreement on the demonstration's route.

In a joint release, Interior minister Bianco and Defense minister, Sergio Mattarella, deny the dossiers collected by the carabinieri may be illegal.

4 Great success of the military parade wished by Ciampi to celebrate the Republic: thousands of people and all political leaders participate, with the exception of Lega secretary, Umberto Bossi.

5 Doctors participate massively in a strike organized to protest the Corte dei Conti, the audit court overseeing the management of the state budget, to approve the salary increases included in the reform the government approved.

The magistrates take side against the law decree on shortened procedures that would allow mafiosi bosses to avoid life sentences.

Bassolino has trouble forming Campania's regional government due to the majority's centrist allies who do not feel sufficiently rewarded by his allocation of councilor posts.

6 The president of the Chamber, Luciano Violante, activates a rule that subjects absent deputies to a fine.

The Corte dei Conti approves doctors' salary raises.

7 The measure on in vitro fertilization, which, when discussed in the Chamber raised objections both in the majority and the opposition, is turned down in the Senate vote; Mancino sends the measure back to a commission, while the majority's centrists and the Polo blame each other.

The Center-Left begins discussion to decide who will lead the coalition at the 2001 national elections.

8 The guarantor of the anti-trust Authority, Giuseppe Tesauro, orders Italian oil companies to pay a 640 billion IL fine because 
of an alleged agreement that resulted in excessive oil price increases; the industry association polemically rejects the accusation.

The president of the Piedmont region, Enzo Ghigo, from the Polo, is unanimously elected head of the Conference of regional presidents.

9 Amato threatens to leave the government if he is not confirmed as the coalition's leader for the 2001 national elections.

12 A CER-CGIL survey claims that one out of four Italian families can make ends meet only because of pensions received by the elderly.

Returns on short-term Treasury bonds, Bot, climb back up to $5 \%$ because of the European Bank's rate increase; the government is concerned about the deficit.

13 Ciampi, under the Pope's request, pardons Ali' Agca, the Pope's attempted killer, who is immediately transferred to a Turkish prison. The episode brings to light divisions among the parties about whether to launch an amnesty degree; FI wants to include corruption crimes, the DS does not.

The thirteenth homicide in thirteen days in Naples is due to an internecine struggle within the Camorra racket.

14 In Bologna, "anti-OECD" demonstrators clash with police during a world meeting organized in order to discuss small and medium sized firms.

16 After the majority agrees to modify the par condicio, the Polo announces it is willing to discuss the new electoral law, taking the German model as a blueprint.

The new Directors of Tg1 and Tg2 -public television's major channels-are named: they are, respectively, Gad Lerner and Maurizio Beretta; the opposition claims it is a "pre-electoral coup."

20 Istat announces the Italian GDP is growing at 3 percent yearly; Amato and Visco express their satisfaction.

After a three-day strike that causes serious problems for individuals and damage to industries, road haulers and the Transportation minister, Pierluigi Bersani, reach an agreement that includes a wage increase.

23 Enrico Cuccia dies: he was 93 years old.

24 According to OECD data, Italy ranks among the worst performing industrial countries with respect to youth employment: one out of three is without a job.

Green gasoline reaches 2,200 IL again.

25 There are protests in all Italian jails by prisoners demanding amnesty. 
26 World meeting in Rome on pedophilia, an issue that, in the aftermath of some cases exposed by the authorities, has recently received much public attention.

Last meeting of IRI, which will transfer its remaining activities and shares to the Treasury minister.

29 Vittorio Gassman, a very popular actor and leader of Italy's cultural scene, dies, at seventy-seven.

30 The Pope appeals to all governments throughout the world asking them to reduce prison terms for jailed criminals; majority and opposition clash again on the types of crimes an eventual amnesty should include.

The Italian parties' balance sheets are published: only PDCI, PRC, Democrats, Lista Pannella and CCD are in the black; debts for more than 10 billion IL for both FI and the DS.

\section{July}

1 Violent clashes occur in the Regina Coeli prison: 25 prison guards are wounded.

3 Indignation surrounds an interview by Berlusconi who characterizes the coach Dino Zoff as "unworthy," following the last minute defeat of Italy's national soccer team in the European championship.

The military Prosecutor's Office dismisses the "Pappalardo case," by arguing that the document issued by the Cocer head did not invite the carabinieri to break the law.

A 19,000 billion IL surplus exists in the state budget, thanks to tax revenues and the proceeds from the sale of IRI-controlled companies; the government announces that the public deficit has been cut in half within the last six months.

4 Zoff, as a result of the controversy with Berlusconi, resigns from his job as coach of the national soccer team.

6 A terrorist attack against a CISL office in Milan is thwarted; the Revolutionary Armed Nucleus (NAR) claims responsibility.

7 After a weeklong controversy, fanned primarily by Church hierarchy, 200,000 people take part in the "Gay Pride" demonstration. Many left leaders, like Walter Veltroni, Emma Bonino, Oliviero Diliberto, and Fausto Bertinotti, participate.

8 The Pope celebrates the prisoners' Jubilee at Regina Coeli; in the course of the ceremony, Giovanni Paolo severely condemns the homosexuals' demonstration: it has been an "insult to the Jubilee.” 
10 According to Bank of Italy data, unemployment is at its lowest since 1994.

The ministry of Public Works announces that Italian cities have the highest mortality rate in Europe due to road accidents.

11 Permits for immigrants who want to settle in Italy nearly reach the ceiling of 63,000 intended for the entire 2000; the ministry of Social Solidarity, Livia Turco, believes the quotas can be changed; the Polo is against such change.

12 In Sicily, Vincenzo Leanza, from UDEUR, becomes president of the regional government with the support of the Polo's parties and some councillors from PPI and RI; Mastella downplays the event, and promises his allies this episode will not affect his party's loyalty to the Center-Left.

13 An Inail report shows that there are 1,200 workplace casualties every year.

The financial liquidators for the former PCI daily L'Unita' are chosen.

14 ISTAT announces a $10 \%$ growth in industrial production during May; the government is satisfied.

The PSI is reborn. Linked to the Polo, it will be led by Claudio Martelli, Gianni De Michelis, Stefania and Bobo Craxi.

15 The government, still worried about oil price increases, delays for the fourth time the 50 liras bonus on fuel prices.

22 Because of the mobilization of youth belonging to social associations in northeastern Italy, Haider has to leave Venice quickly. He had come to support tourism in Carynthia.

Berlusconi publicly announced that he defeated cancer in 1997.

23 Amato declares he wants to remain the Center-Left's candidate at the national elections.

24 Two custom officers drown in Puglia, after an Albanian boat smuggling illegal immigrants rammed their boat; Amato threatens to withdraw Italian aid, unless the Albanian government intervenes.

27 L'Unita' publishes its last issue: journalists take over the newspaper's headquarters.

The Chamber and the Senate approve the DPEF presented by the government for $2001 / 2$.

29 There is protest sit-in in all Italian jails to obtain an amnesty.

30 After many perceived disembarkations of illegal immigrants, Amato lodges an official complaint with Albania, Greece and Turkey, claiming that they are guilty of lax surveillance of their coasts. 


\section{August}

1 De Mauro defends the recruiting of teachers through competitive examination, while the investigation into rigged examinations goes on.

The president of the Antimafia Commission Giuseppe Lumia, who belongs to the Center-Left, states that weapons can sometimes be legitimately used against the drivers of immigrantsmuggling boats.

The judges of the Perugia Crown Court make public the reasons why they absolved Andreotti: there is no sufficient proof.

2 In the course of a ceremony commemorating the Bologna railroad massacre, Amato claims that the investigations on many State massacres have been sidetracked.

5 Edgardo Sogno, former anticommunist partisan leader, decorated with a gold Resistance medal, dies: a State funeral is proclaimed.

7 Seat, a company linked to Telecom, buys 75 percent of Telemontecarlo from Vittorio Cecchi Gori; Mediaset lodges a complaint with Antitrust, while the Polo protests against an acquisition which it claims is against the law.

9 The Osservatore Romano laments the failed impact of the Pope's words about granting a pardon in the year of the Jubilee; majority and opposition have different views of the crimes that ought to be included.

10 Because of inflation, the yearly Bots reach the so-called "psychological" threshold of 5 percent.

According to Confcommercio, the unemployment gap between North and South is widening: 22 percent in the South, 6.7 percent in the North.

11 Dini writes privately to the Austrian government and asks them to keep Haider from planning frequent visits to Italy.

Di Pietro announces he will create his own list for the national elections: a list that will be an alternative to both the Centerright and the Center-Left. There are appeals to the Olive Tree to preserve a common front against the oppositions.

12 The Austrian Foreign Affairs minister, Benita Ferrero-Waldner writes to Dini to reassure him on the strong federalist and antisecessionist values that inspire the Austrian government.

14 A dramatic series of accidents occur during the Ferragosto weekend: 74 die.

16 In Rome, preparations for the "Youth International Day" begin. Haider accuses Dini of lacking democratic values. 
18 Celebrated from the Colosseo to Tor Vergata, the ceremony of the Via Crucis attracts nearly 1.5 million young people.

Controversies within the Center-Left on which candidate ought to be chosen for the upcoming national elections continue. Amato and Rutelli are front runners; Di Pietro puts forward his own candidacy.

19 The "International Day of Youth" succeeds beyond expectations: more than two million young people take part in the vigil the pope celebrates at Tor Vergata.

20 A second homicide occurs within a few days of a first, a child at the hands of a pedophile; the public is disconcerted. There is talk of making public the lists of people accused of pedophilia-related crimes and of using "chemical castration."

25 At the Rimini meeting of Comunione e Liberazione, Veronesi is booed because of his support of scientific experimentation on embryos.

According to Inail data, there are 700,000 new workers since March, as a result of the legalization of the black market.

27 In a reverse exodus back to the cities, 44 people are killed in car accidents.

28 The civil defense announces provisional data showing the environmental damage caused by fires: as many as 65,000 hectares of vegetation are destroyed.

29 At the world medicine congress held in Rome, the Pope says he is in favor of experimentation on embryos, but according to very strict rules dictated by respect for the potential life each embryo represents.

30 Top leaders of the Olive Tree meet to prepare the electoral program for the national elections.

31 Rutelli officially announces he is ready to challenge Berlusconi at the upcoming national elections. Amato claims he does not want to give up the opportunity of becoming the Olive Tree's next leader.

\section{September}

4 Amato makes clear the government intends the fiscal bonus to go to families. In the preceding days, D'Amato had asked for a sharp cut in company taxes, while Cofferati had asked for cuts for the poorest working class strata.

6 Gasoline prices go up again due to increases in the price of oil and the dollar. 
7 The minister Fassino seeks to prevent the death penalty for David Rocco Barnabei, an Italo-American, guilty of homicide; many Catholic associations and human rights groups protest as well; even the Pope intervenes, asking that the condemned prisoner be pardoned.

The telecommunications company Tiscali acquires the Dutch World on Line; the new giant is worth 25,00 billion IL the stock exchange.

8 The Internal Revenue Service increases its receipts: +9.5 percent during the first seven months of the year; the public deficit, though, amounts to more than 2.5 million billions IL.

10 The sudden overflowing of a river causes ten people to die and five to go missing in a campground for the handicapped in Soverato, near Catanzaro; the minister Bianco immediately seeks to identify those responsible for the disaster, whereas the Polo complains that help has been slow in coming.

12 Giuseppe Poggi Longostrevi, a former doctor, and one of the most prominent people investigated by the Milan judges in the nineties, commits suicide.

13 Bologna Cardinal Giacomo Biffi raises a scandal by suggesting that Italy should accept only Catholic immigrants in order to save the nation's identity: the Lega applauds.

15 Formigoni, supported by the Polo and the Lega announces he will organize a regional referendum on devolution; the majority claims it will not accept "the do-it-yourself federalism;" the presidents of Veneto and Piedmont, by contrast, issue enthusiastic comments saying they are ready to follow their colleague.

21 Nine people are arrested in Milan, including the provincial leader of Forza Italia, Massimo Guarischi, and two are indicted by the public prosecutor's office because of corruption-related crimes.

24537 illegal Kurdish immigrants disembark at Capo Rizzuto, in Sicily, after having managed to escape sea surveillance: it is one of the largest groups landed this year.

25 After several days of talks among the majority's various leaders, Amato publicly announces he is stepping aside as candidate for the Olive Tree's leadership; the entire Center-Left thanks the prime minister for the job he has done and for his selfless decision.

26 Istat announces that unemployment is at 10.1 percent.

27 The showing, by Tg1 and Tg2, of very explicit images of pedophiles on the evening news causes a scandal; Lerner apologizes live, while the Polo criticizes RAI's behavior. 
Twenty years after the disaster, the trial against four Italian generals who were accused of having sidetracked the investigations on the Ustica case finally begins.

Pirelli sells its subsidiary Optical, which specializes in optical fibers components, to the American company, Corning. In doing so, it cashes in 6,600 billion IL; on the stock exchange, Pirelli shares soar.

28 Lerner announces he intends to resign as director of Tg1; Rai's board of directors rejects his resignation, while the Polo calls for the company's entire leadership to go.

31 Amato and Visco comment on the budget approved by the government and call it "generous" because of the tax cuts it grants to nearly all groups of citizens.

\section{October}

1 Gad Lerner leaves the editorship of Tg1; he issues a polemical editorial in which he accuses Mario Landolfi, a deputy from AN and chairman of the RAI overseeing commission, of having pressured him into hiring some journalists; the RAI president, Roberto Zaccaria, says he is saddened by Lerner's decision, while Landolfi denies all accusations.

2 After more than three days of uninterrupted dense rain, in the province of Reggio Calabria, more than 1,000 people are evacuated from the areas at risk.

3 The RAI board of directors names Albino Longhi to succeed Lerner; Polo and Olive Tree agree on the choice.

4 On the sixth day of a total strike that has blocked communication, Sicilian road haulers partially loosen the blockade in preparation of a meeting with Bersani; demands concern primarily gasoline and highway tariffs discounts; economic damage is heavy.

5 The Cassation Court rejects a request to revise the Calabresi trial: Sofri, Bompressi and Pietrostefani are declared definitively guilty.

6 Cesare Romiti, in the course of the young industrialists' meeting in Capri, invites the voters not to vote for the Center-Left; majority leaders and the government react with annoyance.

8 Following the signing of a new contract, the international heavy goods vehicles' blockade in Sicily is lifted after nearly ten days of discomfort.

9100,000 teachers demonstrate in Rome to protest against De Mauro's school reform; the target is low wage increases. 
10 Enel, which already owns a majority of Wind, acquires Infostrada, in a deal worth 25,000 billion IL; the Polo criticizes the acquisition as "statalization," whereas Amato defends it. A Green light is also extended to the merger between two banks, Intesa and Comit, in a deal said to be worth 640,000 billion IL.

11 After the Italian proposal for new members of the UN Security Council is rejected, the opposition calls for Dini's resignation.

12 CISL secretary D'Antoni resigns and simultaneously announces his intention to enter politics by creating a new center party.

14 Two days of rain cause serious problems in Piedmont, where more than 1,000 people are evacuated, and in the Aosta Valley, where the provincial capital is isolated due to landslides and overflowing; nearby France sends aid.

16 Problems persist due to bad weather in the North; the dead and missing are being counted; 40,000 have been evacuated. Istat data from August confirm the growth of the Italian economy, at 7.8 percent.

18 The Margherita is born, bringing together the majority's Center parties.

Thirty people are arrested from the teaching and administrative staff of Messina University in the context of an investigation into rigged exams.

Cardinal Angelo Sodano clearly states that there is religious freedom for all those who live in Italy. This was a response to statements by the Lega that sought to prevent the building of a mosque in Lodi.

19 Through an auction for a new generation of cellular frequencies known as "umts," the government expects to raise 50,000 billion IL, based on similar auctions held in other European countries.

20 Inflation drops to 2.5 percent.

One of the participants at the "umts" auction, Blu, has the auction suspended; 23,250 billion IL have been raised thus far. According to the trade unions' estimate, 100 people die every month in Italy in work-related accidents.

22 A large meeting is held at the Milan Palavobis in order to officially designate Rutelli as the candidate of the Olive Tree; majority leaders voice their optimism about the electoral competition.

23 Blu withdraws from the "umts" auction; the government considers whether to fine the participant for foul behavior. The Polo is ironical about the government's forecast, while the stock exchange celebrates cheap licenses, and the public prosecutor's office launches an investigation into whether the auction was conducted according to established rules. 
25 The EU asks Italy to unfreeze prices on auto insurance because the measure goes against the community's norms on free competition.

Lega leader, Bossi, says he is against signing the Nice treaty on the European Rights Charter, thereby embarrassing the House of Freedom.

27 A major round up of pedophiles occurs. 1,032 are arrested and 831 indicted.

Gasoline prices reach a historical high, while green gasoline tops 2,205 IL per liter.

\section{November}

1 Sicily's regional government approves a major amnesty for work done without planning permission for 170,000 illegal houses. Willer Bordon, the Environment minister, calls the decision "unconstitutional."

Cardinal Camillo Ruini, criticized by minister Veronesi, invites Catholic pharmacists to become conscientious objectors and not sell "the-day-after pill."

A dossier by the CGIL states there are more than 400,000 children in Italy that are engaged in child labor.

2 Don Fortunato Di Noto, the priest who helped the Torre Annunziata public prosecutor's office in several investigations of pedophilia, announces he intends to shut down his "Rainbow telephone," and give up collaborating with the law because of the constant pressures and threats to which he has been subjected.

Questioning the constitutionality of the immigration law, Judge Rita Errico sets some illegal immigrants free.

3 The cabinet blocks the proposal by the President of the Veneto Giancarlo Galan to devolve a broad array of powers onto the regions.

4 In the course of the celebration of the Jubilee of politics, the Pope reiterates his request for an amnesty.

Minister Bianco is alarmed by the case of a second judge who, questioning the constitutionality of the immigration law, frees some illegal immigrants who had been jailed and were about to be accompanied to the border.

6 More illegal immigrants are released as a result of constitutionality issues raised about the immigration law.

Some newspapers point to Veltroni as a potential successor of Rutelli for mayor of Rome. 
9 D'Amato intervenes in the debate over the lowering of Irpeg by suggesting the Prime Minister should use his power to veto the eastward enlargement of the EU to blackmail the Commission, were it not to give a green light to the norms already included in the budget.

The Lazio regional council passes a motion creating a commission to evaluate history schoolbooks. The books allegedly do not guarantee the needed cultural pluralism because they are too "pro-marxist."

10 The entire Center-Left protests against the school books proposal of Storace's regional government; even De Mauro and many historians complain. Lombardy, by contrast, is considering following suit, while only AN in its entirety defends the president of the Lazio region.

12 Berlusconi announces that, were he to lose the national elections, he would be ready to retire from politics.

13 "Mad cow" infected meat imported from Northern Europe causes widened concerns; in some cities, schools ban red meat from their cafeterias.

14 The Constitutional Court rejects the "constitutional" referendum proposed by Veneto.

All Italian cities suspend the consumption of beef in school cafeterias.

15 Edoardo Agnelli, son of lawyer Gianni, dies; the most credible hypothesis is suicide.

17 The accusations of the SME trial are restated: Berlusconi is again under accusation by Milan Public Prosecutors. Imports of French meat are blocked because of "mad cow" risk. France demands an explanation from the Italian government.

20 Inflation is at 2.7 percent.

21 The European Commission rejects the proposed reduction of IRPEG for Southern enterprises that had been suggested by D'Amato.

Because of bad weather in most of Central and Northern Italy, several hundred families are evacuated from high-risk areas in Tuscany, Lombardy, Veneto and Fiuli-Venezia Giulia.

23 Giuseppe Gennaro, president of the Magistrates' National Association, states that "Berlusconi has such a low opinion of institutions that I do not believe he could govern;" the entire Polo defends its leader and attacks the magistrate's statement.

24 Amato declares he intends to raise a competence issue with the Constitutional Court against the decision of the Lombardy region concerning "school vouchers for families and students 
in private schools;" he further asks for greater serenity in relations with the magistrates.

25 Thirteen mafia bosses are released from jail because of technical errors in an accusation.

27 The president of the Puglia region, Raffaele Fitto, is attacked, hit and kicked by some unemployed "socially useful workers" whose contracts had not been extended.

28 Minister Veronesi opens the road to the liberalization of light drugs, by branding as "useless" their prohibition. Criticisms come especially from PPI and from many rehabilitation communities. The Chamber approves with a very large majority (but for Rifondazione) the resolution supporting the Charter of European Rights that is due to be discussed at the December European Council in Nice.

After eight years of hearings, the former DC Interior minister, Antonio Gava, is acquitted of the charge of being associated with the mafia.

\section{December}

1 The minister Veronesi attracts the Church's criticisms for supporting the use of condoms as a protection against AIDS.

The president of the Puglia region, Raffaele Fitto, gives back to the government the funds it already disbursed for "socially useful jobs."

4 Berlusconi accuses "some magistrates" of seeking media exposure with their investigations, instead of defending the state.

Savino Pezzotta becomes the new CISL secretary after D’Antoni's resignation.

5 Whereas Ciampi calls for "making a wall against illegal immigrants," the life senators ask him to grant a pardon on occasion of the Jubilee.

6 Ciampi responds to the life senators regarding the pardon by clarifying that the Parliament has the power to make this decision.

Tiscali successfully brings to conclusion the takeover bid launched against Dutch World Online, and conquers fourth place in the European internet access market.

7 Nearly nine out of ten teachers participate in the national strike called by the union federations and by the autonomous teachers' unions to raise salaries in keeping with the European average.

At Milan Scala, the regional councilor for cultural affairs, the leghista Ettore Albertoni, refuses to attend the "prima" in order to manifest his dissent with the government representatives 
attending the event concerning their censorship of the distribution of school vouchers.

8 The INPS announces its deficit has increased, especially because of increased requests for old age pensions (172 percent).

10 In the yearly ranking by the Sole-24 Ore on quality of living in Italian cities, Bologna comes first, while the bottom of the ranking is occupied mostly by southern cities.

12 Giorgio Pannizzari, who had been jailed for terrorist crimes before being pardoned by former president Scalfaro, is arrested after a burglary.

13 Lombardy's former councilor for Public Works, Milena Bertani, is arrested on corruption charges.

14 Demonstrations in all Italian regions by Coldiretti, which claims that at least one million farmers have taken to Italy's streets and squares.

16 Clashes occur between police and left demonstrators in the center of Rome on the occasion of Haider's visit the Pope.

17 Purchases of Christmas presents go up substantially: increases allegedly vary between 15 percent and 30 percent.

18 An unexploded bomb is discovered amidst the spires of the Milan Duomo.

19 The former terrorist Panizzari is accused of having driven the van used by the Red Brigades commando that killed D'Antona. A letter to the Rome daily Messaggero from an anarchist-insurrectionalist organization claims responsibility for the failed attempted attack on the Milan Duomo.

The journalist Bruno Vespa is severely criticized by Rai president, Zaccaria, and by all the main Olive Tree leaders for his barely impartial treatment of Berlusconi in the course of the show "Door to Door."

It is a difficult end of the year for Italian high tech stocks; all are down substantially, especially Tiscati.

20 Inflation is at 2.8 percent, and the growth in the GDP slows down in comparison with the year's early forecast.

21 Mattarella answers to the Chamber concerning the leukemia related deaths of Italian soldiers who participated in peace keeping in Bosnia; a contamination by decayed uranium used in NATO shells is suspected.

ENI launches a "friendly" takeover bid on the British oil company Lasmo; it is one of Italy's largest finance operations on the European market of the year.

22 The bomb he placed in the headquarters of the left daily, Il Manifesto wounds the right wing extremist, Andrea Insabato; 
nobody else is hurt. All political forces condemn the attack; the hypothesis of a comeback of terrorist phenomena is discussed. Naples cardinal, Michele Giordano, is fully acquitted from a usury accusation after an investigation lasting several months; the Vatican manifests its satisfaction.

27 After roughly three days of troubles for travelers and the cancellation of 347 flights because of bad weather, the Malpensa airport goes back to normal functioning. In the midst of criticisms from Minister Bersani and Regional President Formigoni, Giorgio Fossa, the president of company SEA that manages the airport, defends the decision to keep the airport open,

The balance sheet after five days of intense Christmas holiday traffic is 80 dead and more than 1,000 wounded.

28 Albertini, the mayor of Milan, and Sea's majority shareholder, rejects Fossa's resignation.

29 Two spying micro-devices are discovered in the office of the councilor for public works of Lombardy's regional government.

(translated by Serenella Sferza) 